Language Contact 
To the Salish and Pend d'Oreille

elders of Montana who are working to preserve and document their beautiful language: Lemlmtš! 


\section{Language Contact}

SARAH G. THOMASON

EDINBURGH UNIVERSITY PRESS 
(C) Sarah G. Thomason, 2001

Edinburgh University Press Ltd

22 George Square, Edinburgh

Typeset in 10 on 12 pt Times

by Hewer Text Ltd, Edinburgh, and

printed and bound in Great Britain

by MPG Books Ltd, Bodmin

A CIP Record for this book is available from the British Library

ISBN 0748607196 (paperback)

The right of Sarah G. Thomason to be identified as author of this work has been asserted in accordance with the Copyright, Designs and Patents Act 1988. 